University of Montana

ScholarWorks at University of Montana

Ecosystem and Conservation Sciences Faculty

Publications

Ecosystem and Conservation Sciences

2009

\title{
Transport of Fungal Symbionts by Mountain Pine Beetles
}

K. P. Bleiker

S. E. Potter

C. R. Lauzon

Diana Six

University of Montana - Missoula, diana.six@umontana.edu

Follow this and additional works at: https://scholarworks.umt.edu/decs_pubs

Part of the Ecology and Evolutionary Biology Commons

Let us know how access to this document benefits you.

\section{Recommended Citation}

Bleiker, K. P.; Potter, S. E.; Lauzon, C. R.; and Six, Diana, "Transport of Fungal Symbionts by Mountain Pine Beetles" (2009). Ecosystem and Conservation Sciences Faculty Publications. 32.

https://scholarworks.umt.edu/decs_pubs/32

This Article is brought to you for free and open access by the Ecosystem and Conservation Sciences at ScholarWorks at University of Montana. It has been accepted for inclusion in Ecosystem and Conservation Sciences Faculty Publications by an authorized administrator of ScholarWorks at University of Montana. For more information, please contact scholarworks@mso.umt.edu. 


\title{
Transport of fungal symbionts by mountain pine beetles
}

\author{
K.P. Bleiker ${ }^{1,2}$ \\ Department of Ecosystem and Conservation Sciences, University of Montana, Missoula, \\ Montana 59812, United States of America
}

S.E. Potter, C.R. Lauzon

Department of Biological Sciences, California State University, Hayward, California 94542, United States of America

\section{D.L. Six}

Department of Ecosystem and Conservation Sciences, University of Montana, Missoula, Montana 59812, United States of America

\begin{abstract}
The perpetuation of symbiotic associations between bark beetles (Coleoptera: Curculionidae: Scolytinae) and ophiostomatoid fungi requires the consistent transport of fungi by successive beetle generations to new host trees. We used scanning electron microscopy and culture methods to investigate fungal transport by the mountain pine beetle (MPB), Dendroctonus ponderosae Hopkins. MPB transports its two main fungal associates, Grosmannia clavigera (Robinson-Jeffrey and Davidson) Zipfel, de Beer and Wingfield and Ophiostoma montium (Rumbold) von Arx, in sac-like mycangia on the maxillary cardines as well as on the exoskeleton. Although spores of both species of fungi were observed on MPB exoskeletons, often in pits, $O$. montium spores were generally more abundant than G. clavigera spores. However, a general scarcity of spores of either species on MPB exoskeletons compared with numbers on scolytines that lack sac-like mycangia indicates that fungal transport exteriorly on MPBs is incidental rather than adaptive. Conidia were the dominant spore type transported regardless of location or species; however, our results suggest that once acquired in mycangia, conidia may reproduce in a yeast-like form and even produce hypha-like strands and compact conidiophore-like structures. Fungi that propagate in mycangia may provide beetles with a continual source of inocula during the extended egg-laying period.
\end{abstract}

Résumé- La perpétuation des associations symbiotiques entre les scolytes (Coleoptera: Curculionidae: Scolytinae) et les champignons ophiostomatoïdes nécessite un transport continu des champignons par les générations successives de coléoptères vers de nouveaux arbres hôtes. Le microscope électronique à balayage et des méthodes de culture nous ont servi à étudier le transport des champignons chez le dendroctone du pin ponderosa (MPB), Dendroctonus ponderosae Hopkins. MPB transporte ses deux champignons associés principaux, Grosmannia clavigera (Robinson-Jeffrey et Davidson) Zipfel, de Beer et Wingfield et Ophiostoma montium (Rumbold) von Arx, dans des mycanges en forme de sacs sur les cardos des maxilles et sur l'exosquelette. Bien qu'on observe les spores des deux champignons sur l'exosquelette de MPB, souvent dans des fosses, les spores d'O. montium sont généralement plus abondantes que les spores de G. clavigera. Cependant, la rareté générale des spores des deux espèces sur l'exosquelette de MPB par rapport à l'exosquelette de scolytinés qui n'ont pas de mycanges en forme de sacs indique que le transport externe de champignons sur MPB est accidentel plutôt qu'adaptatif. Quels que soit le site et l'espèce, les conidies sont le type dominant de spores transportées; cependant, nos observations indiquent qu'une fois entrées dans les mycanges, les conidies peuvent se reproduire en une forme de levure et même produire des filaments d'hyphes et des structures compactes semblables à des conidiophores. Les champignons qui se reproduisent

Received 12 March 2009. Accepted 22 June 2009.

${ }^{1}$ Corresponding author (e-mail: kbleiker@nrcan.gc.ca).

${ }^{2}$ Present address: Canadian Forest Service, Natural Resources Canada, 506 West Burnside Road, Victoria, British Columbia, Canada V8Z 1M5.

doi: 10.4039/n09-034 
dans les mycanges peuvent fournir aux coléoptères une source continue d'inoculum durant la longue période de ponte des œufs.

[Traduit par la Rédaction]

\section{Introduction}

Ambrosia beetles and bark beetles (Coleoptera: Curculionidae: Scolytinae) are well known for their mutualistic associations with ophiostomatoid fungi (Ascomycota). Potential benefits to scolytine beetles of the association include nutritional supplementation and modification of host-tree tissues by the fungi, which favour brood development (e.g., Whitney 1971; Coppedge et al. 1995; Ayres et al. 2000; Bleiker and Six 2007). Fungi benefit by gaining access to new host trees that would otherwise be inaccessible. These benefits can only be reaped if the partners are able to consistently maintain their association.

Many ambrosia beetles and some bark beetles possess mycangia, which are specialized integumental structures for transporting fungi (Batra 1963). Traditionally the term mycangia has been reserved for sac- or tubelike invaginations of the integument, which may be lined with glands (Six 2003b). Some bark beetles, e.g., Ips typographus L., I. pini (Say), I. sexdentatus Boerner, Scolytus ventralis LeConte, and Dendroctonus pseudotsugae Hopkins, lack sac-like mycangia but still are closely associated with fungi (Livingston and Berryman 1972; Levieux et al. 1989; Furniss et al. 1990, 1995; Lewinsohn et al. 1994). These beetles rely on exterior structures on the exoskeleton, such as pits, to transport their fungal associates. Six (2003b) argued that any structures, such as exterior pits, that consistently transport fungi essentially function as mycangia.

The mountain pine beetle (MPB), Dendroctonus ponderosae Hopkins, has paired sac-like mycangia (glandular status unknown) on the maxillary cardines of both sexes (Whitney and Farris 1970). The most common fungi isolated from the mycangia of MPBs are Grosmannia clavigera (Robinson-Jeffrey and Davidson) Zipfel, de Beer and Wingf. (previously Ophiostoma clavigerum) and Ophiostoma montium (Rumbold) von Arx (Whitney and Farris 1970; Six 2003a; Bleiker and Six 2007; Six and Bentz
2007). MPB is an eruptive, tree-killing bark beetle. Its fungal associates may provide it with nutritional benefits and this may have important implications for its population dynamics (Six and Paine 1998; Bleiker and Six 2007). The fungi may also play a role in overwhelming tree defenses and modifying the phloem in ways that benefit developing brood, like altering chemical and moisture conditions (e.g., Reid et al. 1967; Raffa and Berryman 1983; Yamaoka et al. 1995; Lee et al. 2006; Bleiker and Six 2009). Both species of fungi are also commonly isolated from the exoskeleton of adult MPBs. Six (2003a) found that for beetles caught in flight traps, $G$. clavigera was more often isolated from mycangia than from the exoskeleton, while the reverse was true for $O$. montium. However, no differences were found for preflight adults removed from under bark. Grosmannia clavigera may be better adapted to dispersal in mycangia because MPB has a longer shared evolutionary history with this fungus than with $O$. montium (Six and Paine 1999). Ophiostoma montium may be an opportunistic "cheater" in the system, with spores better adapted for transport on the exoskeleton (Six and Paine 1998, 1999). MPB possesses well-defined pits on the elytra; however, whether or not the pits consistently transport fungi, and thus function as secondary mycangia, is not known.

We used scanning electron microscopes (SEMs) to examine the exterior surface and mycangial openings of adult MPBs to determine where $G$. clavigera and $O$. montium are transported on the body and whether or not exterior structures (e.g., pits, asperites, or setae) consistently transport fungi. We also investigated the morphology of the fungi during transport and whether the two species are differentially transported on the body and in the maxillary mycangia.

\section{Materials and methods}

Adult MPBs used in this study came from near Superior and Butte, Montana 
$\left(47.198905^{\circ} \mathrm{N}, 112.471651^{\circ} \mathrm{W}\right.$, and $45.834137^{\circ} \mathrm{N}$, $112.471651^{\circ} \mathrm{W}$, respectively). At the Superior site, adults were collected from lodgepole pine (Pinus contorta Douglas ex Louden, Pinaceae) trees successfully mass-attacked by MPBs in the summer of 2002. Trees were felled in February 2003, cut into short logs (approximately $60 \mathrm{~cm}$ long), and placed in rearing cages with collection cups. Rearing cages were made from $60 \mathrm{~L}$ plastic bins or garbage cans. Two vents, each approximately $20 \mathrm{~cm} \times 15 \mathrm{~cm}$, were cut in each cage and covered with fine wire mesh and dark cotton cloth. A $6 \mathrm{~cm}$ diameter hole was cut in the side of each cage and a canning-jar sealing ring was glued to the outside of the cage. A $500 \mathrm{~mL}$ glass Mason canning jar containing crumpled paper towelling was screwed onto the sealing ring to serve as a collection cup. Collection cups were emptied every 4-5 d until emergence was complete, and live beetles were stored in a sealed container with moist paper towels at $4{ }^{\circ} \mathrm{C}$ in a refrigerator for $3-10 \mathrm{~d}$ prior to dissection. The same process was used to collect adult beetles emerging from short logs cut from trees attacked by MPBs near Butte in the summers of 2004 and 2005. The Butte logs were cut in July 2005 (from trees attacked in 2004) and July 2006 (from trees attacked in 2005), just prior to brood emergence and the main MPB dispersal flight in the area. Collection cups were emptied every $2-4 \mathrm{~d}$ in 2005 and every $1-2 \mathrm{~d}$ in 2006 until emergence ended. Live beetles were stored as described above for up to $2 \mathrm{~d}$ before dissection.

In 2003, one maxilla was dissected from the head of each of 42 beetles from the Superior population and fixed in $2.5 \%$ glutaraldehyde in $0.1 \mathrm{~mol} / \mathrm{L}$ phosphate buffer and stored at $4{ }^{\circ} \mathrm{C}$ until they were prepared for examination by SEM as follows. Specimens were rinsed two or three times in phosphate buffer (approximately $10 \mathrm{~min}$ each time), rinsed twice in distilled water (approximately $10 \mathrm{~min}$ each time), dehydrated in a graded ethanol series of $50 \%, 70 \%, 95 \%$ (twice), and $100 \%$ (thrice) (approximately $10 \mathrm{~min}$ each time), and dried in a critical-point dryer. In 2005, 20 maxillae, 1 from each of 20 beetles randomly selected from the Butte population, were similarly dissected and the remaining maxilla, severed head, and intact thorax and abdomen of each beetle were prepared for examination by SEM as described above.

In 2006, one maxilla and one elytron were excised from 51 beetles from the Butte population and placed on $2 \%$ malt extract agar (MEA) amended with 100 ppm cyclohexamide. Cyclohexamide reduces contamination by incidental fungi, but the two species of mycangial fungi associated with the MPB are tolerant of this antibiotic. Cultures were stored in the laboratory (at approximately $22{ }^{\circ} \mathrm{C}$ ) for a minimum of 4 weeks before fungal isolates were identified. The second maxilla, head, thorax, abdomen, and one elytron from 20 beetles (randomly selected from the group of 51) were examined by means of the SEM. Samples were prepared for the SEM as described above, except that following dehydration in the graded ethanol series, samples were dried using hexamethyldisilazane because the critical-point dryer was not functional at the time.

All beetle parts were mounted on stubs with carbon-conductive adhesive or silver paste and then coated with gold-palladium (Ted Pella, Inc., Redding, California). The samples from Superior (2003) were examined at the Microscope and Imaging Center at California State University (Hayward). These samples were dried in a Polaron critical-point dryer (Polaron Instruments, Inc., Hatfield, Pennsylvania), coated using a Hummer VII sputtercoating system (Anatech Ltd., Springfield, Virginia) or a Pelco SC-7 Autosputter coater (Ted Pella, Inc.), and examined in a Philips XL 40 SEM (FEI/Philips, Eindhoven, the Netherlands). The Butte samples (2005 and 2006) were processed in the EMtrix Laboratory at the University of Montana and dried in a Balzers 030 critical-point dryer (BAL-TEC AG, Fúrstetum, Liechtenstein), coated using a Pelco Model 3 sputter-coater (Ted Pella Inc.), and examined in a Hitachi S-4700 field emission SEM (Hitachi Inc., Pleasanton, California).

\section{Identification of fungi}

Identification of fungi isolated from excised beetle maxillae and elytra on MEA was based on the morphology of conidia, using light microscopy (Upadhyay 1981). Autoclaved pine twigs were added to all cultures to 
facilitate the identification of $O$. montium, which sporulates readily on pine twigs but not on MEA ( $G$. clavigera sporulates readily on MEA). Cultures were examined after 4 weeks. Spores on bodies and around mycangial openings were similarly identified on the basis of conidial morphology. To facilitate identification, we also used the SEM to examine spores of each species from pure cultures isolated during a previous study (Bleiker and Six 2007). SEMs allow the resolution of some structures (e.g., the hilum) not clearly visible using light microscopy. When objects or cells resembled a species or group of organisms (e.g., yeasts, bacteria), but we were uncertain of identification, we use the suffix "-like".

\section{Data analysis}

Two-tailed exact binomial tests with a hypothesized proportion of 0.5 (i.e., $H_{0}$ : no difference) were conducted to test for potential differences in the frequency of isolations on media between maxillae and exoskeletons for G. clavigera, O. montium, yeasts, and no fungi were isolated. A one-tailed exact binomial test was used to test whether $G$. clavigera was more likely to be isolated from the maxillae than was $O$. montium, given the relative frequencies with which the two species were isolated from the exoskeleton. Because the relative abundances of the two species varied among sites and over time (Bleiker and Six 2007, 2009; Six and Bentz 2007), the proportion of G. clavigera isolated from maxillae was tested against its probability of being isolated from the exoskeleton, to account for its frequency in the beetle population. Thus, the hypothesized proportion used in the one-tailed test was the proportion of all the G. clavigera and (or) $O$. montium isolations from exoskeletons that contained G. clavigera (27 out of 40 isolations, or 0.68 ; see Results) (i.e., $H_{0}$ : probability of G. clavigera isolation from maxillae $>0.68$ ). Binomial tests were conducted using SPSS (SPSS Inc. 2000).

\section{Results}

\section{Morphology of mycangial openings}

Mycangial openings are approximately 26-39 $\mu \mathrm{m}$ long (average $33 \mu \mathrm{m}$ ) and
$3.0-5.5 \mu \mathrm{m}$ wide (average $4.6 \mu \mathrm{m}$ ) medially. They are oblong, with a generalized " $U$ " shape and are slightly constricted at the centre (Fig. 1).

\section{Transport of symbionts}

The Superior beetle population, 2003

Mycangial openings were visible on 25 of the 42 maxillae examined and obscured by muscle tissue or hemolymph on 17 . No fungi or other microorganisms were visible at 4 of the 25 visible mycangial openings. However, spores, yeasts, yeast-like cells, and (or) funguslike growth (hyphae) were visible at 21 openings and often formed a condensed mass, confounding identification (Figs. 2, 3; also see Fig. 8, an example of a condensed spore mass on a beetle from the Butte population). Spores resembling ascospores (sexual spores) of $O$. montium were visible on the palp of one maxilla. An extracellular substance was often associated with the microorganisms at the mycangial opening, but whether it was produced by the beetle, the fungi, or other microorganisms was unclear. Strands resembling hyphae or compact conidiophores were visible protruding from four of the mycangial openings (Fig. 3).

\section{The Butte beetle population, 2005}

Mycangial openings were visible on 11 of the 20 maxillae examined and obscured by muscle processes or hemolymph on 9. Conidia of $G$. clavigera were observed at the opening of only one mycangium (Fig. 4). No spores of O. montium were observed. The opening of one mycangium lacked microorganisms. Yeasts and cells resembling other microbes (possibly bacterial bacilli and cocci) were observed at 10 of the 11 mycangial openings (Fig. 4). Yeasts were usually visible as individual cells at the mycangial opening, but occasionally formed a more condensed mass that may have included spores (see Fig. 2). One cardine broke during dissection of the maxilla, revealing the inside of the mycangium, which was filled with yeast cells embedded in an extracellular matrix (Fig. 5). A comparison of the fungi visible at the mycangial opening with those on the exoskeleton was not possible in 
Figs. 1-3. Mycangial openings on the mountain pine beetle, Dendroctonus ponderosae (MPB): 1, mycangial opening (My) on the maxillary cardine (C) of a MPB from Butte, Montana (2005); 2, condensed mass of yeasts and spore-like objects protruding from a mycangial opening (My) on a MPB from Superior, Montana (2003); 3, hypha- or conidiophore-like strands (H1) extending from a mycangial opening (My) on a MPB from Superior, Montana (2003).

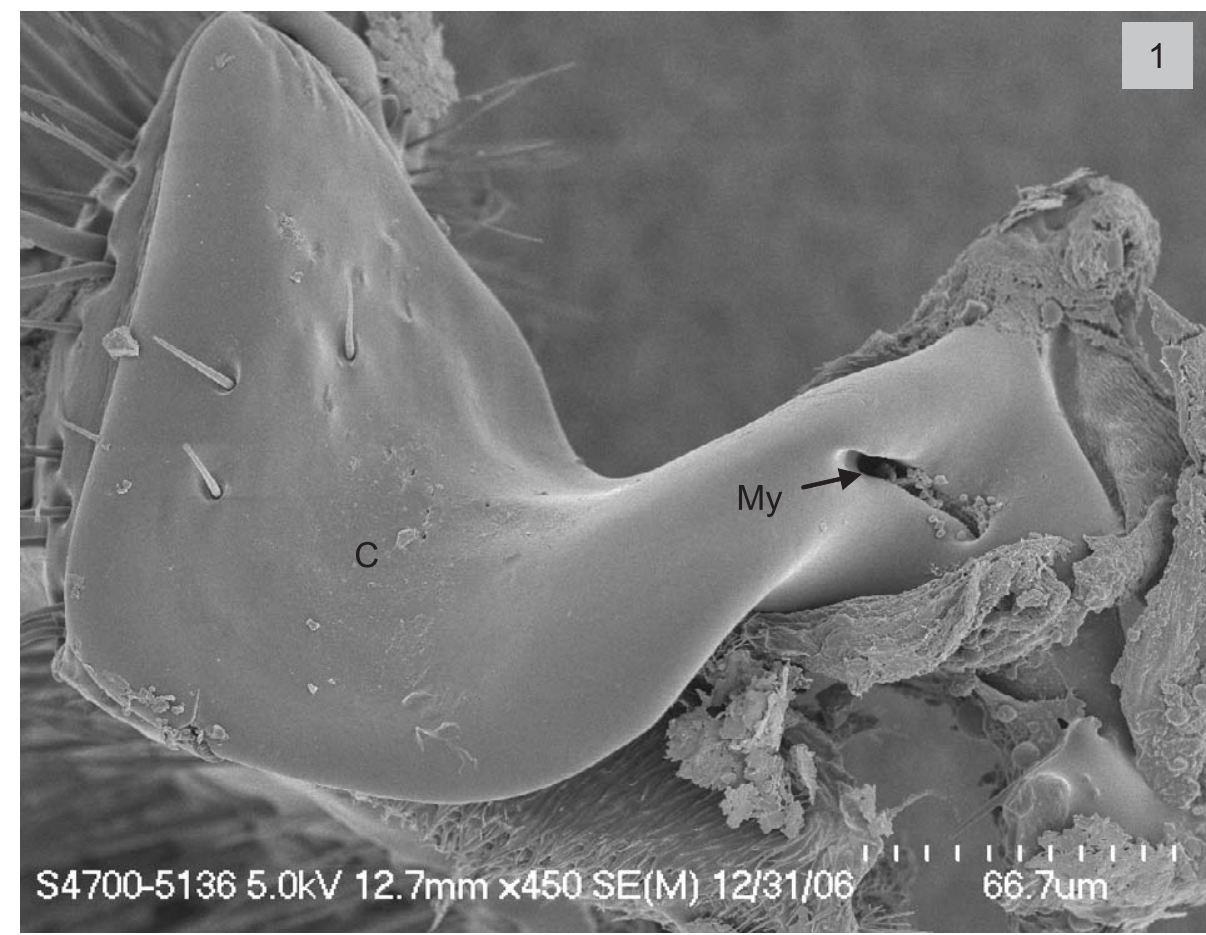

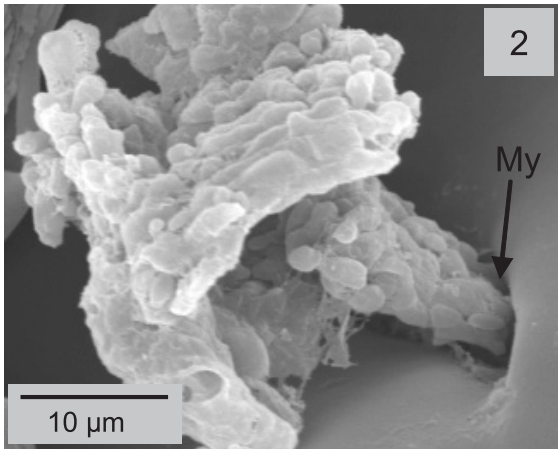

2005 because spores were visible at the mycangial opening on only one beetle, and its body was accidentally destroyed during the mounting process.

The bodies of 19 beetles were examined in the SEM (Figs. 6, 7). Conidia of both $G$. clavigera and $O$. montium were found on the exoskeletons of five beetles (one of these beetles also carried $O$. montium-like ascospores). One body carried only G. clavigera

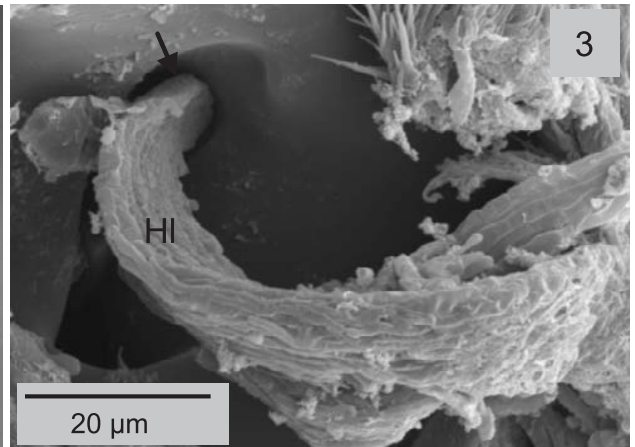

conidia while another carried only $O$. montium conidia. None of the seven beetles with $G$. clavigera or $O$. montium conidia on the exoskeleton had identifiable spores at the mycangial openings. Grosmannia clavigera and $O$. montium conidia were found on all body regions (head, thorax, and abdomen), but were most commonly associated with elytral pits and asperites (Fig. 6). Counting spores grouped in pits was difficult because 
Figs. 4, 5. Microorganisms associated with mycangia of mountain pine beetles, Dendroctonus ponderosae, from Butte, Montana (2005): 4, Grosmannia clavigera conidia (Gc) with the hilum (Hi) visible and bacterium-like cells (B1) embedded in microbial growth at a mycangial opening (My); 5, yeast cells (Y) embedded in an extracellular matrix $(\mathrm{Em})$ inside a mycangium that broke open.
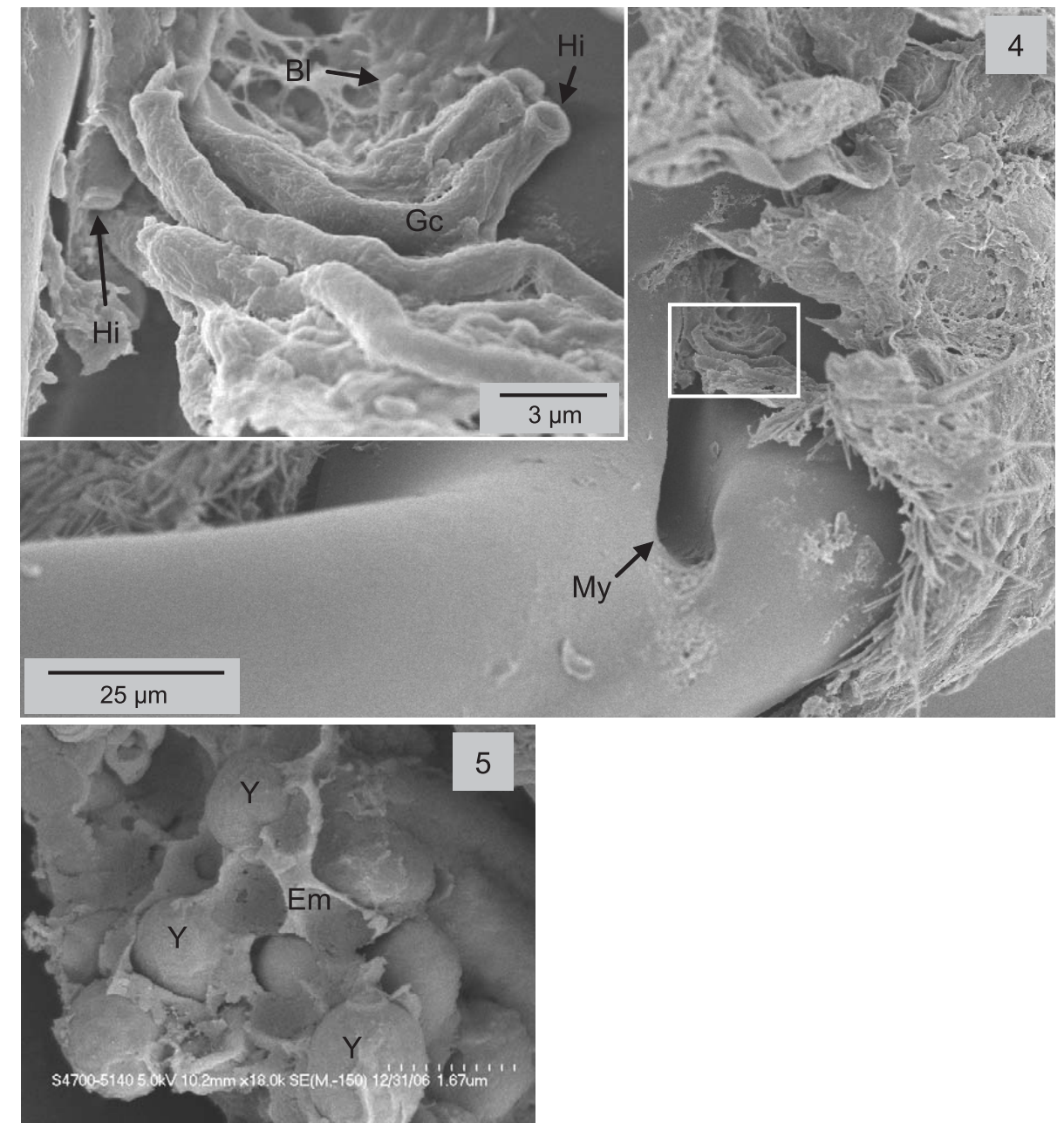

many spores were obscured; however, $O$. montium spores often occurred in groups of a few to about 50, whereas usually only 1 to a few $G$. clavigera spores were found. (The beetle body shown in Figure 6 had an uncharacteristically high spore load compared with all other beetles examined.) The majority of exoskeletal pits were devoid of spores of either species. Yeasts or yeast-like cells were found on the exoskeleton of all beetles, on all regions of the body, but were most commonly lodged at the bases of setae and in elytral pits (Fig. 7).
The Butte beetle population, 2006

In 2006, isolations from one maxilla and one elytron from each of 51 beetles were made on media. Cultures from six of the beetles were contaminated and therefore discarded. Grosmannia clavigera and (or) O. montium were isolated from 31 maxillae and 40 elytra (Table 1). Yeasts were usually isolated along with $G$. clavigera and (or) O. montium from both maxillae and elytra. Yeasts were also isolated from 6 of the 14 maxillae that lacked fungi and from all of the elytra. There were no differences in the probability of isolation from 
Figs. 6, 7. Microorganisms on the exoskeletons of mountain pine beetles, Dendroctonus ponderosae, from Butte, Montana (2005): 6, spores and yeasts predominantly associated with pits (P) or asperites (A) on the elytra; 7, conidia of Ophiostoma montium (Om), showing the hilum (Hi) and hat-shaped yeast-like ascospores (Yhl) in an elytral pit.
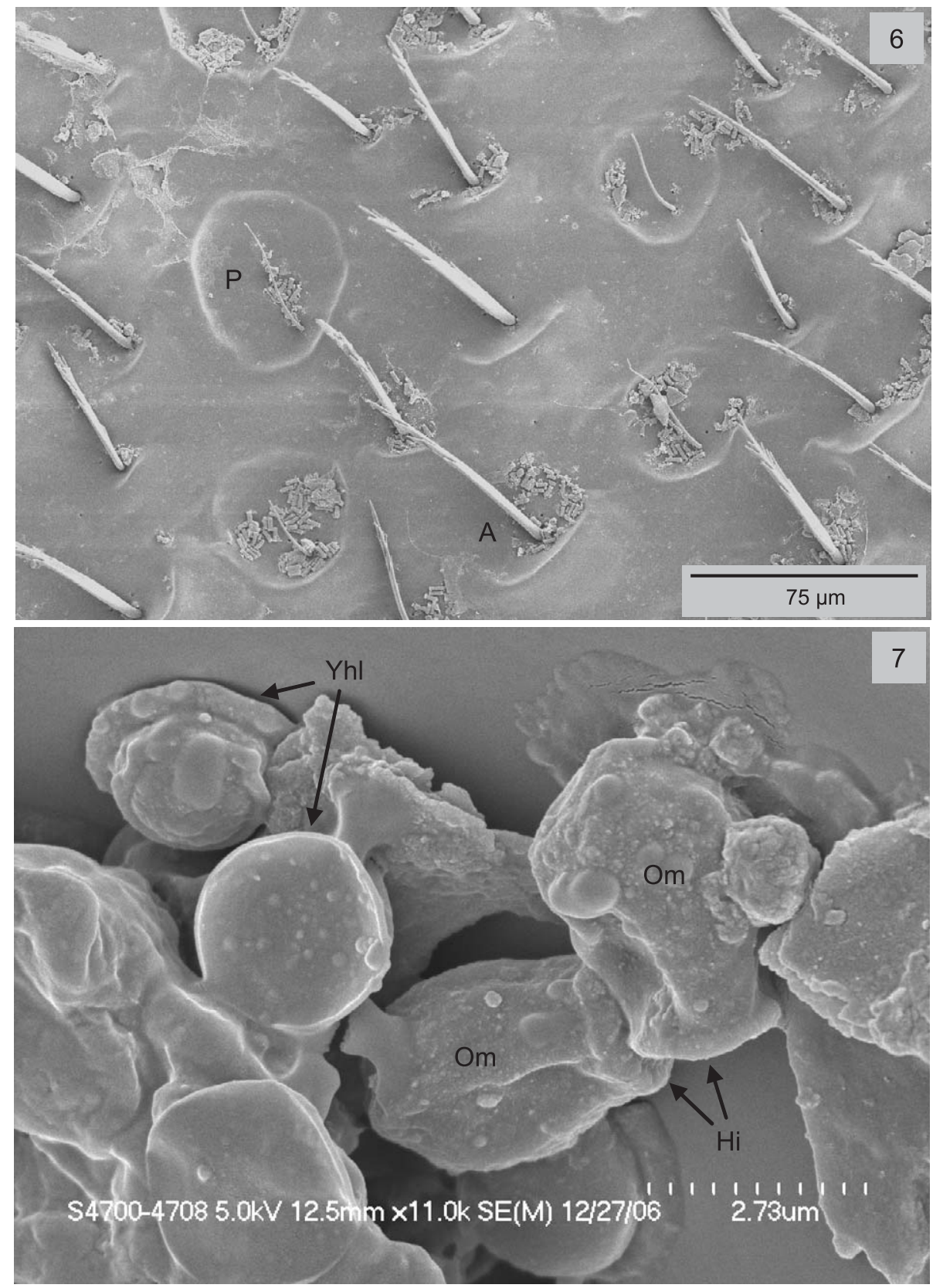

maxillae and exoskeletons of $G$. clavigera $(P=$ $0.57)$, O. montium $(P=0.09)$. or yeasts $(P=$ 1.0). Maxillae, however, were more likely to lack fungi than were exoskeletons $(P=0.008)$.
Grosmannia clavigera was no more likely than $O$. montium to be isolated from maxillae, given the frequency of isolation of the two species of fungi from the elytra $(P=0.21)$. 
Fig. 8. Condensed mass of material, including Grosmannia clavigera-like conidia (Gcl) and Ophiostoma montium-like conidia (Oml), protruding from the mycangial opening of a mountain pine beetle, Dendroctonus ponderosae, from Butte, Montana (2006).

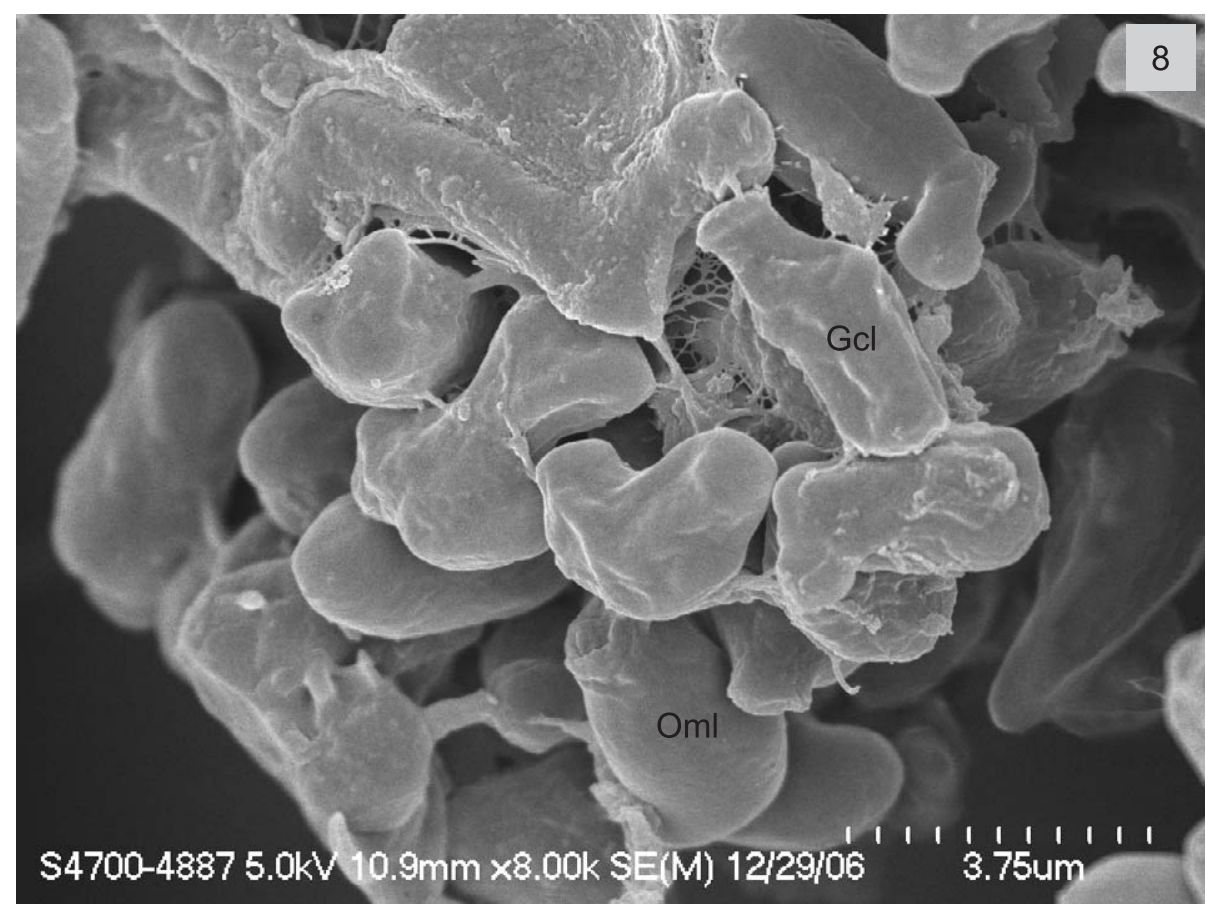

Table 1. Numbers of isolations of Grosmannia clavigera (C) and Ophiostoma montium (M) from maxillae and elytra of adult mountain pine beetles, Dendroctonus ponderosae, collected in Butte, Montana, in 2006.

\begin{tabular}{lccccc}
\hline & \multicolumn{5}{c}{ Elytron $(n=45)$} \\
\cline { 2 - 6 } Maxilla & C only & M only & C and M & No C or M & Total \\
\hline C & 9 & 2 & 3 & 0 & 17 \\
M & 4 & 3 & 2 & 0 & 9 \\
C and M & 0 & 2 & 3 & 0 & 5 \\
No C or M & 2 & 3 & 2 & 0 & 45 \\
Total & 15 & 13 & 12 & 0 & 45 \\
\hline
\end{tabular}

Mycangial openings on 15 of the 20 maxillae examined in 2006 were visible using the SEM. Three of the 20 beetle bodies were obscured by resin and discarded. Neither $G$. clavigera nor $O$. montium spores were present at 13 of the 15 visible mycangial openings. There were spores or spore-like objects at two mycangial openings (Fig. 8), but spores of both species of fungi were observed on the majority of exoskeletons (Table 2). Fungi were isolated from seven of the second maxillae from each pair of maxillae taken from these from 15 beetles (Table 3). Over two-thirds of isolations from paired elytra taken from beetles upon which spores of one or both species of fungi were observed using the SEM yielded at least one of the species. However, often only one fungal species was isolated from bodies on which spores of both species had been observed (Table 3). Spores of both species were observed on all body regions. As in 2005, few spores, especially of 
Table 2. Numbers of observations (using scanning electron microscopy) of spores of Grosmannia clavigera (C) and Ophiostoma montium (M) at mycangial openings and on corresponding bodies of adult mountain pine beetles, Dendroctonus ponderosae, collected in Butte, Montana, in 2006.

\begin{tabular}{lccccc}
\hline & \multicolumn{5}{c}{ Body $(n=14)$} \\
\cline { 2 - 6 } Mycangial opening & C only & M only & C and M & No C or M & Total \\
\hline C & 0 & 0 & 0 & 0 & 0 \\
M & 0 & 0 & 0 & 0 & 0 \\
C and M & 0 & 0 & $2 *$ & 0 & 2 \\
No C or M & 2 & 1 & 9 & 0 & 12 \\
Total & 2 & 1 & 11 & 0 & 14 \\
\hline
\end{tabular}

*Includes one mycangial opening with G. clavigera- and O. montium-like spores (see Fig. 8).

Table 3. Numbers of observations of spores of Grosmannia clavigera (C) and Ophiostoma montium (M) at a mycangial opening and isolated from the corresponding paired maxilla or observed on the body and isolated from the corresponding excised elytron of adult mountain pine beetles, Dendroctonus ponderosae, collected in Butte, Montana, in 2006.

\begin{tabular}{|c|c|c|c|c|c|c|c|c|c|c|}
\hline \multirow[b]{3}{*}{$\begin{array}{l}\text { Visible } \\
\text { (SEM) }\end{array}$} & \multicolumn{10}{|c|}{ Isolated (malt-extract agar) } \\
\hline & \multicolumn{5}{|c|}{ Mycangia (maxilla) $(n=15)$} & \multicolumn{5}{|c|}{ Elytron $(n=17)$} \\
\hline & C only & M only & $\mathrm{C}$ and $\mathrm{M}$ & $\begin{array}{l}\text { No C } \\
\text { or } \mathrm{M}\end{array}$ & Total & C only & M only & $\begin{array}{c}\mathrm{C} \text { and } \\
\mathrm{M}\end{array}$ & $\begin{array}{l}\text { No C } \\
\text { or } \mathrm{M}\end{array}$ & Total \\
\hline $\mathrm{C}$ & 0 & 0 & 0 & 0 & 0 & 0 & 1 & 1 & 0 & 2 \\
\hline M & 0 & 0 & 0 & 0 & 0 & 0 & 0 & 1 & 1 & 2 \\
\hline $\mathrm{C}$ and $\mathrm{M}$ & $1 *$ & 1 & 0 & 0 & 2 & 1 & 2 & 6 & 4 & 13 \\
\hline No $\mathrm{C}$ or $\mathrm{M}$ & 4 & 1 & 2 & 6 & 13 & 0 & 0 & 0 & 0 & 0 \\
\hline Total & 5 & 2 & 2 & 6 & 15 & 1 & 3 & 8 & 5 & 17 \\
\hline
\end{tabular}

Note: Observations were made with the SEM; isolations were made using culture methods described in the text.

*Includes one mycangial opening that had G. clavigera- and O. montium-like spores (see Fig. 8).

G. clavigera, were found on exoskeletons. Yeasts were observed at three mycangial openings and isolated from 11 of the 15 maxillae. Yeasts were visible on the exoskeletons of all beetles examined and were most abundant at the bases of setae and in pits. Yeasts were isolated from all elytra.

\section{Discussion}

MPB is able to transport both $G$. clavigera and $O$. montium in maxillary mycangia as well as on the exoskeleton, primarily in pits. However, usually only small groups of spores were found on the exoskeleton. Exoskeleton pits were not as full of spores as in scolytines that lack sac-type mycangia and rely solely on pits to transport their fungal symbionts (e.g., I. typographus, I. pini, I. sexdentatus, $S$. ventralis, and $D$. pseudotsugae) (Livingston and Berryman 1972; Levieux et al. 1989; Furniss et al. 1990, 1995; Lewinsohn et al. 1994). Also, we found no evidence of a waxy or oily substance in pits on MPBs that has been associated with some beetles that transport symbionts in pits and may protect spores from desiccation (Livingston and Berryman 1972; Lewinsohn et al. 1994). Spore load was likely not affected by the preparation process because the beetles were first placed in fixative. Furthermore, Lewinsohn et al. (1994) used a similar preparation method and found numerous spores in pits on the exoskeleton of $D$. pseudotsugae. The collection method may affect spore load; Six (2003a) 
isolated G. clavigera more frequently from the exoskeletons of preflight MPBs removed from under bark than from beetles caught in flight traps. However, MPBs examined in this study were collected shortly after they emerged from logs and thus would be expected to have a high spore load because beetles acquire spores in the pupal chamber just prior to emergence (Whitney 1971). Although pits, asperites, and setae can trap spores, we found no evidence that any of these structures functioned as secondary mycangia for MPBs.

Based on the presence/absence of G. clavigera and $O$. montium, we found no evidence that one species was better adapted for transport on the body than the other. However, often only one to a few G. clavigera conidia occurred together, in contrast to larger groups of $O$. montium conidia, indicating that $O$. montium may adhere better to the exoskeleton. Although we and others have isolated $G$. clavigera and $O$. montium from MPB exoskeletons (Six 2003a; Lee et al. 2006; K.P. Bleiker and D.L. Six, unpublished data), we observed relatively few spores (especially those of G. clavigera) on exoskeletons.

The size of the mycangial opening and our fortuitous view of the inside of a mycangium on a broken cardine demonstrate that mycangia are large enough to accommodate conidia of all sizes produced by $O$. montium and some conidia produced by $G$. clavigera (1.5-8 and 2-85 $\mu \mathrm{m}$ long, respectively) (Upadhyay 1981; Tsuneda and Hiratsuka 1984). Based on physical size, $O$. montium conidia should enter mycangia more easily than $G$. clavigera conidia can. We found no evidence that one species was more likely than the other to be present in mycangia when the presence of fungi on exoskeletons was considered. However, we have no data on mycangial spore load for either of the fungal species or on their ability to reproduce.

Observations of spores at mycangial openings varied among years, which may have been due to differences in collection and storage times and fungal reproduction in the mycangia. The quantity of spores acquired in MPB mycangia during pre-emergence feeding and their ability to germinate or propagate within mycangia are unknown. Whitney and
Farris (1970) proposed that fungal associates of the MPB undergo a morphological change in the mycangia. Fungal associates of many ambrosia beetles and at least two bark beetle species multiply within mycangia and can exist in a yeast-like state (which complicates their identification on the basis of morphology) (e.g., Batra 1963; Abrahamson et al. 1967; Barras and Perry 1971, 1972; Paine and Birch 1983). If the MPB generally acquires only a few conidia in a mycangium and those conidia then reproduce by budding, this could explain the high percentage of mycangial openings on beetles collected in 2006 that appeared to be empty. These beetles were collected and dissected within a shorter time frame than in 2003 and 2005, and fungal propagules in their mycangia may not have had time to reproduce and fill the opening. Grosmannia clavigera and O. montium are capable of reproducing by budding and are more likely to do so under certain environmental and nutritional conditions (Upadhyay 1981; Tsuneda and Hiratsuka 1984) that could exist within mycangia. Budding could also facilitate mycangial transport of G. clavigera (which has longer conidia than $O$. montium). Based on growth forms visible at mycangial openings, and the fact that either G. clavigera or O. montium is usually isolated from mycangia, it seems likely that these fungi exist in mycangia in an altered state and are capable of reproduction by budding, and spores may even germinate within the mycangium (as evidenced by hyphal-like strands and compact conidiophore-like structures; Fig. 3).

In addition to spores of $G$. clavigera and O. montium, yeast cells, hat-shaped yeast-like ascospores, and bacterium-like cells (bacilli and cocci) were present at some mycangial openings and on exoskeletons. Yeasts and bacteria are well-known associates of bark beetles, although less is known about their role in the system than for G. clavigera and O. montium. Yeasts and bacteria may be involved in synthesis of beetle pheromones (Brand et al. 1975), digestion of tree tissues (Delalibera et al. 2005), nitrogen fixation (Bridges 1981), and insect mortality (Moore 1972).

Mycangia have evolved independently several times in bark beetles (Six 2003b), which 
suggests that they play an important role in maintaining the continuity of the bark beetle -fungus association between generations. Our results indicate that although MPB commonly carries some $G$. clavigera and $O$. montium conidia on the body, such external transport of fungi is likely incidental, and a result of circumstances, rather than being an adaptive response. Conidia appear to be the dominant spore type transported by MPB regardless of their location on the body. Our results also support the hypothesis that after MPB acquires conidia in its mycangia, the fungi then reproduce in a yeast-like state and even germinate and produce hyphae. The yeast-like cells and hyphae exuding from mycangia would inoculate new host trees as parent beetles construct egg galleries. It seems that MPB could simply acquire enough conidia from pupal chambers to inoculate future host trees and avoid any energy costs associated with maintaining and supporting fungal reproduction within mycangia. However, egg-gallery construction extends over a period of weeks, with females continually extending galleries into fresh, uncolonized phloem. We hypothesize that actively growing hyphae or the budding, yeast-like state of mycangial fungi provide a continual (regenerating) supply of inocula over an extended period, increasing the rate at which tree tissues are colonized by the fungal symbionts of MPB. This would facilitate contact between the mutualists and allow MPB to rapidly reap the benefits of the symbiosis.

\section{Acknowlegements}

We thank R. Pescador, B. Granath, and J. Driver for technical advice and S. Whitney and L. Safranyik for a helpful discussion. The manuscript was improved by reviews from $C$. Fiedler, B. Bentz, and two anonymous reviewers. This research was funded through an operating grant from the National Institutes of Health IDeA Networks of Biomedical Research Excellence / Biomedical Research Infrastructure Networks (INBRE-BRIN) to the Electron Microscopy Laboratory at the University of Montana and a Sigma Xi Grants-in-Aid of Research award to K.P.B.

\section{References}

Abrahamson, L.P., Chu, H.M., and Norris, D.M. 1967. Symbiotic interrelationships between microbes and ambrosia beetles. II. The organs of microbial transport and perpetuation in Trypodendron betulae and $T$. retusum (Coleoptera: Scolytidae). Annals of the Entomological Society of America, 60: 1107-1110.

Ayres, M.P., Wilkens, R.T., Ruel, J.J., Lombardero, M.J., and Vallery, E. 2000. Nitrogen budgets of phloem-feeding bark beetles with and without symbiotic fungi. Ecology, 81: 2198-2210.

Barras, S.J., and Perry, T.J. 1971. Gland cells and fungi associated with prothoracic mycangium of Dendroctonus adjunctus (Coleoptera: Scolytidae). Annals of the Entomological Society of America, 64: $123-126$.

Barras, S.J., and Perry, T.J. 1972. Fungal symbionts in the prothoracic mycangium of Dendroctonus frontalis. Zeitschrift für Angewandte Entomologie, 71: 95-104.

Batra, L.R. 1963. Ecology of ambrosia fungi and their dissemination by beetles. Transactions of the Kansas Academy of Science, 66: 213-236. doi: $10.2307 / 3626562$.

Bleiker, K.P., and Six, D.L. 2007. Dietary benefits of fungal associates to an eruptive herbivore: potential implications of multiple associates on host population dynamics. Environmental Entomology, 36: 1384-1396. PMID:18284766 doi:10. 1603/0046-225X(2007)36[1384:DBOFAT]2.0.CO;2.

Bleiker, K.P., and Six, D.L. 2009. Competition and coexistence in a multi-partner mutualism: interactions between two fungal symbionts of the mountain pine beetle in beetle-attacked trees. Microbial Ecology, 57: 191-202. PMID:1854 5867 doi:10.1007/s00248-008-9395-6.

Brand, J.M., Bracke, J.W., Markovetz, A.J., Wood, D.L., and Browne, L.E. 1975. Production of verbenol pheromone by a bacterium isolated from bark beetles. Nature (London), 254(5496): 136-137. PMID:804144 doi:10.1038/254136a0.

Bridges, J.R. 1981. Nitrogen fixing bacteria associated with bark beetles. Microbial Ecology, 7: 131-138. doi:10.1007/BF02032495.

Coppedge, B.R., Stephen, F.M., and Felton, G.W. 1995. Variation in female southern pine beetle size and lipid content in relation to fungal associates. The Canadian Entomologist, 127: 145-154.

Delalibera, I., Jr., Handelsman, J., and Raffa, K.F. 2005. Contrasts in cellulolytic activities of gut microorganisms between the wood borer, Saperda vestita (Coleoptera: Cerambycidae), and the bark beetles, Ips pini and Dendroctonus frontalis (Coleoptera: Curculionidae). Environmental Entomology, 34: 541-547.

Furniss, M.M., Solheim, H., and Christiansen, E. 1990. Transmission of blue-stain fungi by Ips typographus (Coleoptera: Scolytidae) in Norway 
spruce. Annals of the Entomological Society of America, 83: 712-716.

Furniss, M.M., Harvey, A.E., and Solheim, H. 1995. Transmission of Ophiostoma ips (Ophiostomatales: Ophiostomataceae) by Ips pini (Coleoptera: Scolytidae) to ponderosa pine in Idaho. Annals of the Entomological Society of America, 88: 653-660.

Lee, S., Kim, J.J., and Breuil, C. 2006. Diversity of fungi associated with the mountain pine beetle, Dendroctonus ponderosae, and infested lodgepole pines in British Columbia. Fungal Diversity, 22: 91-105.

Levieux, J., Lieutier, F., Moser, J.C., and Perry, T.J. 1989. Transportation of phytopathogenic fungi by the bark beetle Ips sexdentatus Boerner and associated mites. Journal of Applied Entomology, 108: 1-11.

Lewinsohn, D., Lewinsohn, E., Bertagnolli, C.L., and Patridge, A.D. 1994. Blue-stain fungi and their transport structures on the Douglas-fir beetle. Canadian Journal of Forest Research, 24: 2275-2283. doi:10.1139/x94-292.

Livingston, R.L., and Berryman, A.A. 1972. Fungus transport structures in the fir engraver, Scolytus ventralis (Coleoptera: Scolytidae). The Canadian Entomologist, 104: 1793-1800.

Moore, G.E. 1972. Microflora from the alimentary tract of healthy southern pine beetles, Dendroctonus frontalis (Scolytidae), and their possible relationship to pathogenicity. Journal of Invertebrate Pathology, 19: 72-75. doi:10.1016/00222011(72)90191-7.

Paine, T.D., and Birch, M.C. 1983. Acquisition and maintenance of mycangial fungi by Dendroctonus brevicomis LeConte (Coleoptera: Scolytidae). Environmental Entomology, 12: 1384-1386.

Raffa, K.F., and Berryman, A.A. 1983. Physiological aspects of lodgepole pine wound responses to a fungal symbiont of the mountain pine beetle, Dendroctonus ponderosae (Coleoptera: Scolytidae). The Canadian Entomologist, 115: 723-734.

Reid, R.W., Whitney, H.S., and Watson, J.A. 1967. Reactions of lodgepole pine to attack by Dendroctonus ponderosae Hopkins and blue stain fungi. Canadian Journal of Botany, 45: 11151126. doi:10.1139/b67-116.
Six, D.L. 2003a. A comparison of mycangial and phoretic fungi of individual mountain pine beetles. Canadian Journal of Forest Research, 33: 1331-1334. doi:10.1139/x03-047.

Six, D.L. 2003b. Bark beetle - fungus symbioses. In Insect symbiosis. Edited by K. Bourtzis and T.A. Miller. CRC Press, New York. pp. 97-114.

Six, D.L., and Bentz, B.J. 2007. Temperature determines symbiont abundance in a multipartite bark beetle - fungus ectosymbiosis. Microbial Ecology, 54: 112-118. PMID:17264992 doi:10. 1007/s00248-006-9178-x.

Six, D.L., and Paine, T. 1998. Effects of mycangial fungi and host tree species on progeny survival and emergence of Dendroctonus ponderosae (Coleoptera: Scolytidae). Environmental Entomology, 27: 1393-1401.

Six, D.L., and Paine, T. 1999. Allozyme diversity and gene flow in Ophiostoma clavigerum (Ophiostomatales: Ophiostomataceae), the mycangial fungus of the Jeffrey pine beetle, Dendroctonus jeffreyi (Coleoptera: Scolytidae). Canadian Journal of Forest Research, 29: 324-331. doi:10. 1139/cjfr-29-3-324.

SPSS Inc. 2000. SPSS. Version 10.0. SPSS Inc., Chicago, Illinois.

Tsuneda, A., and Hiratsuka, Y. 1984. Sympodial and annellidic conidiation in Ceratocystis clavigera. Canadian Journal of Botany, 62: 2618 2624.

Upadhyay, H.P. 1981. A monograph of Ceratocystis and Ceratocystiopsis. University of Georgia Press, Athens, Georgia.

Whitney, H.S. 1971. Association of Dendroctonus ponderosae (Coleoptera: Scolytidae) with blue stain fungi and yeasts during brood development in lodgepole pine. The Canadian Entomologist, 103: $1495-1503$.

Whitney, H.S., and Farris, S.H. 1970. Maxillary mycangium in the mountain pine beetle. Science (Washington, D.C.), 167(3914): 54-55. PMID: 17759499 doi:10.1126/science.167.3914.54.

Yamaoka, Y., Hiratsuka, Y., and Maruyama, P.J. 1995. The ability of Ophiostoma clavigerum to kill mature lodgepole pine trees. European Journal of Forest Pathology, 25(6-7): 401-404. doi:10.1111/j.1439-0329.1995.tb01355.x. 